\title{
University Governance and Campus Speech
}

\author{
L.W. Sumner \\ sumner@chass.utoronto.ca
}

A university department has invited a controversial academic speaker to deliver a series of three lectures. A group of left-wing students considers some of the speaker's writings, especially his analysis of the causes of Black urban poverty, to be racist. At the first event the speaker is harassed by a few members of the audience but is able to deliver his lecture. At the second, some students take over the platform in order to prevent the lecture from proceeding. As a result, the second and third lectures are cancelled.

Sound familiar? Instances of disruption, disinvitation, or 'no-platforming' of invited speakers have recently become commonplace on university campuses, especially in the United States. ${ }^{1}$ But the foregoing event was not recent, and it occurred in Canada. The speaker in question was the well-known conservative sociologist Edward Banfield, the host of the planned lecture series was the Department of Political Economy at the University of Toronto, and the date was March $1974 .^{2}$ At the time the university was heavily criticized for its handling of the affair, especially for its failure to ensure that the remaining lectures could go forward without disruption. University administrators continue to face criticism for the ways in which they choose to intervene, or not to intervene, in speaking events held on their campuses. Clearly the fact that these problems are not new has not made them any easier to solve.

In its broadest form, the question we have before us is this: When university administrators learn of a planned speaking event on campus that looks likely to be contentious or problematic, how should they respond? What would ethical leadership look like in these

\footnotetext{
${ }^{1}$ The Foundation for Individual Rights in Education (FIRE) has catalogued over 400 "disinvitation attempts", about half of them successful, at American universities since 2000. https://www.thefire.org/research/disinvitationdatabase/\#home/?view_2_per_page=1000\&view_2_page=1. Retrieved 12/10/2020. ${ }^{2}$ Martin L. Friedland, The University of Toronto: A History (Toronto: University of Toronto Press, 2013), 539-41.
} 
circumstances? In this form, however, the question is too broad. As one way of narrowing it, I will specify that 'university administrators' are here to be understood as those with the ultimate responsibility for overseeing such events (usually the academic vice-president). Similar questions may apply to more junior levels of administration (deans, directors, department chairs, etc.), but I will confine my attention to the desk where the buck stops.

We also need a more focussed understanding of the ways in which campus speech might be 'contentious or problematic'. At one time obscenity might have been an issue (imagine that the campus film society announces a screening of Deep Throat), but those issues have latterly rather receded from view. The dominating concern of today is hate speech, understood broadly as any form of expression that is intended to arouse hatred or contempt toward members of a particular social group. I will follow that trend, so that our question now becomes: When top university administrators have reason to believe that a planned speaking event on campus may feature hate speech (at least in the eyes of some), how should they respond?

In what follows I will address that question (or at least some aspects of it) as it arises for Canadian universities. With that setting in mind, some legal context is important. In Canada, unlike the United States, hate speech is regulated by criminal law. Section 319(2) of the Criminal Code prohibits 'communicating statements, other than in private conversation' that 'wilfully promote hatred against any identifiable group'. ${ }^{3}$ For the purpose of this section, an 'identifiable group' is defined as 'any section of the public distinguished by colour, race, religion, national or ethnic origin, age, sex, sexual orientation, gender identity or expression, or mental or physical disability'. ${ }^{4}$ It is worth noting that in order to secure a conviction for promoting hatred it is both necessary and sufficient to establish that the speaker intended that effect; they need not actually have achieved it.

\footnotetext{
${ }^{3}$ This is the provision that was upheld as constitutional by the Supreme Court of Canada in R. v. Keegstra, [1990] 3 S.C.R. 697.

${ }^{4}$ Criminal Code, S. 318(4).
} 
The law of the land applies everywhere, including on university campuses. So if a campus speaker is unwise enough to engage in hate speech, within the meaning of the statute, then they expose themselves to the possibility of a charge and of prosecution. In this event, there is no role for university administrators; enforcement of the criminal law is a police matter. (Actually, there may be a role for administrators, but I will return to that later.)

Furthermore, administrators would be unwise to take pre-emptive action — even action that falls short of cancelling the event - in anticipation that an invited speaker might cross the line. In March 2010 the American right-wing commentator Ann Coulter was scheduled to give a talk at the University of Ottawa. Prior to the event the university's academic vice-president sent Coulter a warning, cautioning her to watch her words lest she face criminal charges for promoting hatred. Coulter subsequently cancelled the event, not strictly because of the warning, but because sponsors feared that demonstrations outside the venue might turn violent. In a subsequent interview, Coulter did not neglect the opportunity to mock the university: 'It's at the absolute bush league, bottom of the barrel schools that you get the worst treatment and still I've never seen this before. I'm guessing the scores to get into the University of Ottawa are not very challenging. ${ }^{5}$

The legal restrictions of hate speech are, however, only part of the story, and ultimately not a very important part. As I have said, when those restrictions are transgressed in campus speech, university administrators have little to do except let the law take its course. The more serious and difficult question concerns campus speech that is hateful without rising to the level of a criminal offence. Freedom of expression enjoys constitutional protection under section 2(b) of the Charter of Rights and Freedoms. In order not to offend the Charter, the bar for a successful prosecution for hate promotion has been set very high, by providing speakers with a formidable array of defences. Besides the obvious defence of truth, a speaker's statements are also

\footnotetext{
${ }^{5}$ Steven Chase, “Ann Coulter's speech in Ottawa cancelled", The Globe \& Mail, March 23, 2010. https://www.theglobeandmail.com/news/politics/ann-coulters-speech-in-ottawacancelled/article4352616/. Retrieved 07/10/2020.
} 
immunized against prosecution if they 'were relevant to any subject of public interest, the discussion of which was for the public benefit, and if on reasonable grounds he believed them to be true'. ${ }^{6}$ That's a loophole that only the most extreme, or obtuse, speaker could fail to take advantage of. (Perhaps the University of Ottawa administration should also have informed Coulter of that fact.)

The implication of all this for university administrators is that campus speech may be hateful without being unlawful. The waters are further muddied by the fact that the key components of the hate speech law are themselves vague and contentious; what may appear to some as an attempt to arouse hatred will look to others as honest and tough-minded political commentary. As an example, let's use Israeli Apartheid Week (IAW), a series of lectures and rallies that is held annually on some Canadian campuses. The avowed aim of its organizers is to 'educate people about the nature of Israel as an apartheid system' and to build support for a global Boycott, Divestment, and Sanction campaign against Israel. ${ }^{7}$ So far, it seems to fit comfortably within the bounds of political speech critical of Israel, and neither the organizers nor the speakers have ever been charged with promoting hatred. However, many of these events have been accused by observers, Jewish and non-Jewish alike, of being anti-Semitic. ${ }^{8}$ Since the law of the land is not in play here, the burden of deciding whether to respond to Israeli Apartheid Week, and if so in what way, falls squarely on the shoulders of university administrators.

Campus events featuring right-wing provocateurs like Ann Coulter are likely to fall in the same grey area. Coulter, who has argued that American immigration policies amount to the genocide of white people,$^{9}$ is fully capable of incendiary remarks calculated to offend some racial

\footnotetext{
${ }^{6}$ Criminal Code, s. 319(3). In addition to these defences, prosecution for hate promotion also requires the consent of the provincial Attorney General or Minister of Justice. Partly for this reason, Ernst Zündel, the notorious Holocaust denier, was never prosecuted in Canada for promoting hatred.

7"About Israeli Apartheid Week". https://web.archive.org/web/20090224200120/http://apartheidweek.org/en/about. Retrieved 07/10/2020. ${ }^{8}$ See, for example, the 2012 statement by Jason Kenney, then Minister of Citizenship, Immigration, and Multiculturalism: https://cjpac.ca/statement-by-minister-jason-kenney-condemning-israel-apartheidweek/. Retrieved 07/10/2020.

${ }^{9}$ https://en.wikipedia.org/wiki/Ann_Coulter\#Immigration. Retrieved 08/10/2020.
} 
or religious or ethnic constituency on campus. But what she has to say is also unlikely to rise to the level of a criminal offence, even if she is not tutored on Canadian law in advance of her appearance.

What is the appropriate response by the university administration in advance of these sorts of events? Would there ever be grounds for intervening to cancel any of them? I want to think about this question in the following way. ${ }^{10}$ The jurisdiction of university administrators over speaking events ends at the boundaries of their campus. It would be equally open to some off-campus group to stage Israeli Apartheid Week, or to invite Coulter to speak, at a venue elsewhere in the community. In that case, municipal officials would face the same decision whether to allow the event to proceed. We can then ask whether the factors to be taken into account in making this decision are the same on- and off-campus. Do university administrators have more reason to intervene in a situation like this, or less? Should the bounds of free speech be narrower on campus, or broader? (Or, perhaps, just the same.)

There are arguments to be made for each option, arguments that speak to the special nature and mission of the university. The strongest case in favour of a very broad free speech zone on campus invokes the traditional idea of the university as a domain with a distinctive commitment to open and free inquiry. The University of Toronto puts this point in the following way:

...the essential purpose of the University is to engage in the pursuit of truth, the advancement of learning and the dissemination of knowledge. To achieve this purpose, all members of the University must have as a prerequisite freedom of speech and expression, which means the right to examine, question, investigate, speculate, and comment on any issue without reference to prescribed doctrine... ${ }^{11}$

\footnotetext{
${ }^{10}$ I owe this way of thinking about it to Michael Marrus.

${ }^{11}$ University of Toronto, "Statement on Freedom of Speech". https://governingcouncil.utoronto.ca/sites/default/files/202003/Freedom\%20of\%20Speech\%2C\%20Statement\%20on\%20Protection\%20of\%20.pdf. Retrieved $08 / 10 / 2020$. The University of Toronto's position here is not anomalous. Very similar statements can be found at most Canadian post-secondary institutions.
} 
It seems to follow from this conception of the university's mission that speakers should be free to express, and audiences should be free to hear, all opinions on matters of public interest, however odious or offensive to some those opinions might be. The University of Toronto draws this very conclusion:

The University must allow the fullest range of debate. It should not limit that debate by preordaining conclusions, or punishing or inhibiting the reasonable exercise of free speech. $^{12}$

The University of Chicago has taken a very similar position in a widely influential statement of principle:

Because the University is committed to free and open inquiry in all matters, it guarantees all members of the University community the broadest possible latitude to speak, write, listen, challenge, and learn.... [I]t is not the proper role of the University to attempt to shield individuals from ideas and opinions they find unwelcome, disagreeable, or even deeply offensive.... [T] he University's fundamental commitment is to the principle that debate or deliberation may not be suppressed because the ideas put forth are thought by some or even by most members of the University community to be offensive, unwise, immoral, or wrong-headed. It is for the individual members of the University community, not for the University as an institution, to make those judgments for themselves, and to act on those judgments not by seeking to suppress speech, but by openly and vigorously contesting the ideas that they oppose. ${ }^{13}$

These 'Chicago Principles' have subsequently been adopted or endorsed at more than seventy post-secondary institutions across the United States.

On this view of the university's purpose, its administrators should be particularly reluctant to shut down campus speech, possibly more reluctant than their counterpart municipal

\footnotetext{
${ }^{12}$ Ibid.

${ }^{13}$ University of Chicago, "Report of the Committee on Freedom of Expression". https://provost.uchicago.edu/sites/default/files/documents/reports/FOECommitteeReport.pdf. Retrieved $08 / 10 / 2020$.
} 
authorities, who lack the same sense of mission. In that case, the bounds of free expression must not be narrower on campus than they are in the nonacademic world, and arguably should be wider.

Arguments for the contrary view, however, are also rooted in a conception of the peculiar nature of the university. I will consider four of them.

1. The argument from academic freedom. One version of this argument has been articulated and defended in a recent article by Robert Mark Simpson. ${ }^{14}$ As Simpson conceives of it, academic freedom resembles free speech in guaranteeing a wide-ranging liberty of expression and inquiry, but differs from it by applying strictly within the special scholarly domains of teaching and research. ${ }^{15}$ Within these domains, Simpson argues, it is accompanied by the expectation that scholarly work is properly 'subject to quality controls on the basis of general professional standards of accuracy and coherence', ${ }^{16}$ controls for which, he suggests, there is no real analogue in the case of non-scholarly on-campus speaking activities. Simpson's argumentative target is this misalignment between academic freedom and campus speech; the standards of the former, he argues, should be applied to the latter:

...[S]peech expressing ill-informed or badly reasoned ideas need not receive any special protection in universities, except if it falls under the protection of academic freedom, for example, if it occurs as part of the university's formal teaching and research activities. Free speech is a fundamental liberty in social intercourse per se, but it is not a mandatory commitment for the university. Thus, we can at least sometimes exclude or marginalize speakers and ideas that fall short of the intellectual standards which define academia and conduce to its core epistemic aims. ${ }^{17}$

\footnotetext{
${ }^{14}$ Robert Mark Simpson, “The Relation Between Academic Freedom and Free Speech,” Ethics 130, no. 3 (2020).

${ }^{15}$ Simpson often gives the impression that academic freedom belongs exclusively to university faculty, in their professional pursuits. But surely it applies equally to students in their scholarly activities. The salient distinction is between teaching and research, on the one hand, and the manifold other activities, including speaking activities, that can occur on university campuses.

${ }^{16}$ Ibid., 291.

${ }^{17}$ Ibid., 316.
} 
It follows from Simpson's analysis that speech that might be properly allowed in the wider community may properly be disallowed on campus. Simpson proposes that speaking invitations by campus groups be vetted, not by university administrators, but by faculty experts in the appropriate field. (This vetting would apply to all campus speakers, not just those thought likely to promote hatred.) 'And where the considered judgment of the institution's academic experts is that an invited speaker's work manifestly fails to attain to the kind of intellectual standards that further its epistemic mission, then, other things being equal, that institution should refrain from offering a platform to that speaker.' ${ }^{18}$

I leave to others to imagine how well a system requiring speaker invitations by student groups to be approved by faculty experts might work out in practice. There is, it seems to me, a much deeper problem with Simpson's analysis and proposal. Let's return to his starting point, the topic of academic freedom. According to the Canadian Association of University Teachers:

Academic freedom includes the right, without restriction by prescribed doctrine, to freedom to teach and discuss; freedom to carry out research and disseminate and publish the results thereof; freedom to produce and perform creative works; freedom to engage in service; freedom to express one's opinion about the institution, its administration, and the system in which one works; freedom to acquire, preserve, and provide access to documentary material in all formats; and freedom to participate in professional and representative academic bodies. Academic freedom always entails freedom from institutional censorship. ${ }^{19}$

Notable by its absence from this statement is any reference to the quality of the work that academics are to be free to engage in; they are equally free to carry out their teaching and research, without institutional interference, whether they do it well or badly. Of course, they are expected by the university to do it well, and the quality of their performance is constantly being

\footnotetext{
${ }^{18}$ Ibid., 317.

${ }^{19}$ CAUT Policy Statement: “Academic Freedom”. https://www.caut.ca/about-us/caut-policy/lists/cautpolicy-statements/policy-statement-on-academic-freedom. Retrieved 08/10/2020.
} 
assessed for purposes such as tenure, promotion, and remuneration. But these assessments are a matter not of academic freedom but of academic or professional standards. If a faculty member is denied tenure or promotion on the basis of negative assessments of the quality of their teaching or research, this outcome is not a restriction of their academic freedom but a judgement of their failure to live up to professional expectations. ${ }^{20}$

Simpson constantly conflates the two, to the detriment of his argument. That argument actually has little to do with academic freedom and rests instead on the premise that the standards that are appropriate in classroom teaching, in research seminars, in professional conferences and workshops, and in the preparation of scholarly work for publication should also be applied outside these contexts to all other activities on campus. ${ }^{21}$ Any invited speaker whose credentials fail to meet these standards may properly be denied a campus platform. That high bar will suffice to exclude Ann Coulter, and possibly also some of the presenters at Israeli Apartheid Week, as well as a host of other nonacademic speakers who may not hold advanced degrees or qualify as experts in their field. However, these invited speakers are not engaged in any of the aforementioned scholarly activities, nor are they contending for tenure, promotion, or a salary increase; instead, they have been solicited because they have been deemed to have something worthwhile to say on some matter of public interest. Despite their lack of academic credentials, there may still be much to learn from them.

2. The argument from civility. Simpson also makes the related point that discourse in scholarly settings - in classrooms, research seminars, etc.- - is expected to be civil. (Anyone who has attended many academic presentations knows that they are not always civil.) Uncivil discourse can lead to distress on the part of targeted audience members, which Simpson suggests 'is out of place on the campus common, for much the same reason that it is out of place in the seminar

\footnotetext{
${ }^{20}$ Of course, the former can be, and undoubtedly has been, disguised as the latter. Nonetheless, they are fundamentally different.

21 " The picture that I am recommending is one in which the communicative climate of the campus at large is characterized by similar kinds of rigor, thoughtfulness, and deference to academic expertise to those of the lecture theater or faculty research seminar." (ibid., 299)
} 
room itself. It is a kind of distress which is not integral to the targeted individual's learning experience, and which can greatly detract from it. ${ }^{22}$ This is now a rather different ground for regulating campus speech. Speakers need not be experts, and need not measure up to lofty academic standards, and may in principle espouse any opinions they like, as long as they do so in a civil manner. Ann Coulter and Israeli Apartheid Week will still not make the cut, but now for a different reason.

Since we all think civility a good thing, this is an appealing idea. However, those who contend that the university may rightly suppress uncivil speech must face the question how this might be accomplished. Incivility admits of many gradations, from the merely ill-mannered to the scurrilous and abusive. Where is the line to be drawn at what is acceptable on campus, and who is to draw it? Most university administrators seem to show little relish for serving as the arbiters of civility. The University of Toronto states that '...although no member of the University should use language or indulge in behaviour intended to demean others..., the values of mutual respect and civility may, on occasion, be superseded by the need to protect lawful freedom of speech.'23 The University of Chicago takes an even stronger stand: 'Although the University greatly values civility, and although all members of the University community share in the responsibility for maintaining a climate of mutual respect, concerns about civility and mutual respect can never be used as a justification for closing off discussion of ideas, however offensive or disagreeable those ideas may be to some members of our community., 24

Simpson's appeal to civility serves to remind us that we need to distinguish two different kinds of restraint on speech. Content restrictions stipulate certain ideas or opinions that may not be expressed by any speaker on any occasion. ${ }^{25}$ Holocaust denial might serve as a case in point. Context restrictions, by contrast, will permit the expression of these ideas or opinions, but not at

\footnotetext{
${ }^{22}$ Ibid., 300 .

${ }^{23}$ Op. cit.

${ }^{24}$ Op. cit.

${ }^{25}$ Simpson further muddies the waters by conflating content restrictions with the application of professional standards to scholarly work: ibid., 292-4.
} 
the wrong time, or in the wrong place, or in the wrong manner. John Stuart Mill, who rejected content restrictions on speech, was alive to this distinction. The opinion that corn dealers are starvers of the poor, he says, may be freely circulated through the press but may not be delivered to an angry mob assembled in front of the corn dealer's house. ${ }^{26}$ Civility constraints are context restrictions on campus speech: you may express hateful views, but only in language that is subtle and coded, rather than forceful and blunt. For the most part, the hate promotion section of the Criminal Code imposes a content restriction: you may not use language that wilfully promotes hatred against an identifiable group (unless you are saved by one of the available defences). However, it also contains a context restriction: you are not liable if you use that language 'in private conversation'. There is a strong case to be made that university administrators should not be in the business of imposing content restrictions on campus speech. Time, place, and manner restrictions, however, may be another matter.

The 'Chicago Principles' stipulate that 'the University may reasonably regulate the time, place, and manner of expression to ensure that it does not disrupt the ordinary activities of the University'. The University of Toronto Statement on Freedom of Speech is more specific: 'Of necessity, there are limits to the right of free speech, for example, when members of the University use speech as a direct attack that has the effect of preventing the lawful exercise of speech by members or invited guests, or interfering with the exercise of authorized University business, the University may intervene.'

It follows from this statement that in the Banfield affair the university would have been justified in suppressing the speech (and conduct) of the protesting students in order to permit Banfield's lectures to proceed. In fact, we can say something stronger: acting in this way would have been not merely permissible, but obligatory. To this point we have been tacitly assuming that the duties of university administrators vis-à-vis campus speech are entirely negative: duties not to intervene, for instance, by cancelling or shutting down speaking engagements. But much

\footnotetext{
${ }^{26}$ John Stuart Mill, On Liberty, ed. David Bromwich and George Kateb (New Haven and London: Yale University Press, 2003), 121.
} 
more germane are positive duties to facilitate or enable speech events, by not permitting others to shut them down. This was the signal failing of the University of Toronto administration in 1974: it should have taken steps to ensure that Banfield's two remaining lectures could be delivered at a time and in a place where they could be protected from intervention by protestors, if necessary by the use of campus, or even municipal, police. The protesting students were entitled to advocate their point of view, but not in such a way as to suppress Banfield's speech.

The university may therefore be permitted, or even required, to intervene when campus speech becomes sufficiently unruly or disruptive. But this does not give it a licence to screen all speaking events for possible incivility. It is not Israeli Apartheid Week or a talk by Ann Coulter that is likely to have the effect of 'preventing the lawful exercise of speech', but rather the reactions of their opponents.

3. The argument from student protection. Simpson's appeal to civility noted the distress that uncivil speech can cause to 'targeted audience members'. However, this point could be broadened to apply to hate speech in general. There is no reasonable doubt that racist, sexist, or homophobic discourse can hurt its intended targets. The university already has the responsibility to protect vulnerable students, as much as it can, against such threats as racist bullying and sexual harassment. It would therefore be but a short step to argue that it should also take steps to protect them from the hurt that can be inflicted by insults or abuse.

However, I am skeptical that universities have this in loco parentis function of sheltering their students against the pernicious effects of hate. For one thing, the very idea of making the campus a 'safe space' in this respect seems quixotic. In the age of social media, hate speech is pervasive; it does not respect campus boundaries and students cannot be insulated against it. Unlike other vectors on which hatred can spread unchecked, scheduled on-campus speaking events have the great advantage of being optional and easily avoided; if you don't want to listen to Ann Coulter fulminate about Mexicans or Muslims, then you need only give her talk a miss. In any case, if the university does indeed have this protective responsibility toward its students, then there is a more constructive way for it to fulfil it than by preventing them from hearing 
controversial speakers. One function the university clearly does have is to teach students to think critically, to demand evidence for opinions, to challenge outlandish assertions, and to see through lies, distortions, and misrepresentations. If it has done its job, then it will have equipped them to fight back against hateful speech with the weapons of facts and logic. University administrators who consider no-platforming speakers show no confidence in the ability of their students to call out hateful rhetoric for what it is. If anything, students should be less in need of protection against the hurtful effects of extreme speech than members of the broader community who have not had the same educational advantages.

4. The argument from legitimization. This argument is often put in the following form: when a university hosts an event like Israeli Apartheid Week, or a speaker like Coulter, it implicitly legitimizes the opinions that will thereby be espoused. Universities, it will be said, are prestigious institutions, and so their prestige will rub off on their invited speakers. Neil Levy puts this point nicely, in a slightly more technical way. Levy distinguishes between two kinds of evidence for a speaker's opinions: first-order evidence, which consists in the arguments for and against those opinions, and higher-order evidence, which bears on determining whether the speaker's opinions deserve to be taken seriously.

An invitation to speak at a university campus, a prestigious event or to write an opinion piece for a newspaper provides (prima facie) higher-order evidence. It is evidence that the speaker is credible; that she has an opinion deserving a respectful hearing. It typically certifies expertise, and expertise is higher-order evidence that the person's opinion should be given particular weight.... ${ }^{27}$

There is clearly something to this argument. When an academic unit in a university (a faculty, department, centre, etc.), or a group of faculty members in such a unit, issues an invitation to a visiting speaker, they are indeed implying that this person has the appropriate credentials to contribute something worthwhile on their announced topic. After all, the members

\footnotetext{
${ }^{27}$ Neil Levy, "Why No-Platforming is Sometimes a Justifiable Position," Aeon.https://aeon.co/ideas/whyno-platforming-is-sometimes-a-justifiable-position.
} 
of the unit in question have the expertise to determine who is, and who is not, worth listening to, and they have no interest in wasting their time, and their colleagues' time, on second-raters or charlatans. So such an invitation does constitute higher-order evidence of credibility. Having been an invited speaker at the highly rated Department of $X$ at the internationally renowned University of Y can add luster to any curriculum vitae. In the case of these invitations, however, it is hard to imagine university administrators having grounds to overrule the academic judgements of their colleagues.

The point, however, does not generalize to other campus speaking events, especially invitations by student groups. They may well lack the expertise to distinguish wheat from chaff, or may decide to invite someone, like Coulter, just because they are provocative, or have celebrity status, or are likely to fill the hall. A speaking invitation from a student group will often not constitute higher-order evidence of expertise or credibility, in which case university administrators have no more reason to no-platform a campus speaker than do their municipal counterparts. We are reminded here again of Simpson's distinction between the more scholarly domains of the university and the rest of the campus: the conventions and assumptions that apply to the former may have no purchase in the latter. ${ }^{28}$

Levy's point, however, does apply particularly forcefully to one category of speaker invitations: those issued by the university itself. In inviting someone to address commencement, for instance, the university administration is clearly certifying this person as having the requisite knowledge or experience to deliver a message it would benefit the graduating students to hear. It is therefore very important for university administrators to vet proposed commencement speakers carefully, so as to avoid those with a history of espousing views that are demeaning or blatantly

\footnotetext{
${ }^{28}$ Of course, Coulter will record the fact that she spoke at the university, not that she was hosted there by some fringe campus group. So a little of the prestige of the institution will inevitably rub off on her. This unfortunate reality is not, at least by itself, sufficient justification for denying her a campus platform.
} 
unscientific. As some universities have discovered to their regret, the cost of not doing their homework can be high. ${ }^{29}$

To recapitulate, the question I have been addressing is whether the bounds of free speech should be broader or narrower on campus than in the outside world. Broader limits are supported by the mission of the university to promote and protect free inquiry. Four arguments were then canvassed on the other side of the question: that campus speech should be held to the high standards of scholarly discourse, that uncivil speech should be discouraged or suppressed, that students deserve special protection from hate, and that university platforms can confer legitimacy on speakers with hateful or otherwise objectionable messages. My conclusion is that none of these latter arguments succeed, thus that the bounds of free speech should be at least as broadand arguably should be broader — on the university campus as they are elsewhere in the community.

This result is good news for university administrators. As far as the regulation of campus speech is concerned, what ethical governance will demand of them will nearly always be: absolutely nothing. They will have reason to become actively involved only in order to ensure that a speaking event proceeds safely, or when it threatens to disrupt the functioning of the university, or when it is itself threatened with disruption by protesting groups. In those instances the justification for intervention will be to protect and facilitate speech, not to shut it down.

Acknowledgements: I am grateful to Tom Hurka, Cheryl Misak, and Kent McNeil for very valuable comments on an earlier draft of this paper.

\footnotetext{
${ }^{29}$ In 2009 Ben Stein, the actor and game show host, was invited to deliver a commencement address at the University of Vermont. It then came to light that Stein was an enthusiastic denier of evolution and advocate of intelligent design creationism. After a letter-writing campaign to protest the invitation, including such prominent figures as Richard Dawkins, Stein agreed to withdraw from the talk. See "Ben Stein Backs Out of Commencement Gig at Vermont over Views on Evolution", Chronicle of Higher Education, February 3, 2009. https://www.chronicle.com/article/ben-stein-backs-out-of-commencementgig-at-vermont-over-views-on-evolution/. Retrieved 14/10/2020
} 
